$\underline{\xi}=-5$

\title{
Proximate, GC-FID, and micronutrient analysis of extracts of azadirachta indica
}

\author{
Amadi Benjamin ${ }^{1}$, Emelieze Mary ${ }^{1}$, Agomuo Emmanuel ${ }^{2}$, Ogunka-Nnoka Charity ${ }^{1}$, and Amadi Peter ${ }^{1 *}$ \\ ${ }^{1}$ Department of Biochemistry, University of Port Harcourt, Choba Rivers State Nigeria \\ ${ }^{2}$ Department of Biochemistry, Imo State University Owerri, Imo State Nigeria \\ *Corresponding author E-mail: peter_amadi@uniport.edu.ng
}

\begin{abstract}
Different extraction media applied on the pulverized leaves of Neem plant (Azadirachta indica) were analyzed for its proximate, phytochemical, and micronutrient compositions, predominantly using the gas chromatographic technique. The results showed that the ethanol extract contained the highest amounts of carbohydrates and fibre. No significant difference ( $>0.05)$ was recorded for the protein and ash content of both ethanol and methanol extracts, while the moisture and fat contents occurred highest in aqueous and methanol extracts respectively. The phytochemical screening revealed the absence of glycosides in all the extracts while steroids were found only in methanol and ethanol extracts. The aqueous extracts contained greater amounts of epicate chin (13.42\%), lunamarine (5.81\%), tannin $(19.18 \%)$ and phytates $(0.27 \%)$, but lacked anthocyanin, phenol and kaempferol, while rutin (77.54\%), ribalinidine (2.06\%), oxalate $(1.23 \%)$, anthocyanin $(1.16 \%)$, and sparteine $(0.05 \%)$ occurred highest in the ethanol extract. Only sparteine was lacking in the methanol extract. No significant difference was recorded between the aqueous and ethanol extracts for the vitamin A, D, C, and $\mathrm{B}_{2}$ contents, while except for vitamin $B_{3}(0.22 \mathrm{mg} / 100 \mathrm{~g})$ and vitamin $\left.\mathrm{K}(0.08 \mathrm{mg} / 100 \mathrm{~g}), 08 \mathrm{mg} / 100 \mathrm{~g}\right)$, the methanol extracts contained the least amounts of the vitamins evaluated. Manganese, zinc, copper, calcium and lead contents of the methanol extract were significantly higher than those of the other extracts while the aqueous extract contained the highest amount of sodium. This study has provided the scientific backing for the application of a specific extraction medium during the exploitation of distinct phytochemicals, while water, ethanol, and methanol should be the preferred extraction media for vitamins, proximate and dietary mineral contents respectively.
\end{abstract}

Keywords: Proximate; Vitamins; Minerals; Phytochemicals; Neem Plant

\section{Introduction}

Herbal medicine is regarded as one of the foremost medical practices believed to have been central to ushering in the present modern pharmaceutical trade. Plants with well known medical uses are referred to as medicinal plants, and these plants are found growing in different localities over the world. With such a long history of working with medicinal plants, most chemists have vested interests in plants with paucity of information in order to investigate their active components and their corresponding mechanisms of action. In most cases, the target is to produce a synthetic version of the compound reproducible in the laboratory and utilizable by pharmaceutical companies. Medicinal plants are used by over $80 \%$ of the rural communities all over the world for the provision of primary health care services (Prajapati and Prajapati, 2002; Latif et al., 2003; Shinwari et al., 2006) and besides the presence of pharmacologically active components, each plant posses a unique nutrient content. The nutrients also contribute towards the satisfaction of energy requirements for various metabolic processes (Hoffman et al., 1998; Matthews et al., 1999; Dingman et al., 2002). Further, clinicians and medical practitioners are faced with the challenge of minimizing the numerous cases associated with drug resistance, and the screening of medicinal plants for their active components has received enormous attention as a suitable alternative. Natarajan et al., (2003) reported that manipulations of these compounds enable the provision of improved drugs used for the treatment of various diseases. The Azadirachta indica plant (known as dogonyaro in Nigeria) taxonomy is of the Meliaceae family (Callahan, 2010; Bharti et al., 2012). It is a tree that blossoms during the dry season with height of about 20-23m (Girish and Neem, 2008). It is a decidous plant that sheds its leaves during the harmattan periods in Nigeria. The neem branches spread widely revealing the fairly roundish dense crown (Krishan et. al., 2011). The neem tree (Azadirachta indica) also known as Nim tree and India lilac is very similar in appearance to its relative known as China-berry (Mellia azedarach) which is a mahogany family of Meliaceae (Krishan et al., 2011) of Azadirachta indica species. Neem is widely used for its various therapeutic effects. According to the reports of Sithisarn et al., (2005) and Ghimeray et al., (2009) the leaves of neem have proven antioxidant properties, while Kumar et al., (2010) have shown the antimutagenic effects of neem against 7,12-dimethylbenz(a)anthracene. Further, other notable medicinal properties of neem include hepatoprotective effect (Bhanwra, 2000; Baligar et al., 2014), antiinflammatory (Kaur et al., 2004; Mosaddek and Rashid, 2008), antinephrotoxic effect (Abdel Moneim et al., 2014), neuroprotective effects (Abdel Moneim, 2014), and growth promoting and immunomodulatory effects (Durrani et al., 2008). Notwithstanding these reported medicinal properties to the neem plant, the utilization of different extraction solvents has led to widely differing outcomes. This might be related to the ability of these solvents to extract different phytoconstituents both in amount of and properties and amount. It is on this note that this study compared the 
nutrient contents of Azadirachta indica, on application of various extraction mediums.

\section{Materials and methods}

\subsection{Sample collection and preparation}

Fresh leaves of Azadirachta indica were obtained from bushes in University of Port Harcourt. The leaves were thoroughly washed with water to remove debris and air dried. The samples were ground using a mechanical grinder and soaked in water, ethanol, and methanol prior to analysis.

\subsection{Determination of proximate composition}

Proximate analyses of the samples for carbohydrate, crude fat, ash, crude protein, fiber and moisture contents were carried out according to standard methods of AOAC (1990).

\subsection{Phytochemical screening and phytochemical deter- mination using GC-FID method}

The methods of Sofowora, (1980) and Harborne (1973) were applied for the qualitative detection of phytochemicals in the samples. Quantitative phytochemical analysis of the oil samples was carried out using an auto system buck 530 chromatographer in gas phase equipped with an on-column automatic injector, flame ionization detector, and with Hp88 capillary column (100m x $0.25 \mathrm{~mm}$ ). Chromatographic conditions were; injector temperature $220^{\circ} \mathrm{C}$, detector temperature $250^{\circ} \mathrm{C}$, oven temperature to $180^{\circ} \mathrm{C}$ injection volume $1 \mathrm{ml}$ sample, hydrogen was used as a carrier gas ( 24 pound per square inch (PSI)). The concentration of each active component was determined based on the ratio between the area and mass of internal standard and area under the peaks of the phytochemicals identified.

\subsection{Determination of vitamin composition}

The vitamin content was analyzed by a modification of AOAC, (2006). The sample was subjected to the laboratory atmospheric condition on the bench after removing the samples from the storage chamber at $4^{0} \mathrm{C}$. The sample was pressed and completely homogenized in the mortar carefully with pestle to avoid forming balls. The homogenized sample $(0.10 \mathrm{~g})$ was weighed into a beaker after extraction; the extract was concentrated to $1.0 \mathrm{ml}$ and for analysis, using a HP 6890 Gas chromatographic apparatus fitted with pulse flame photometric detector (PFPD) using Nitrogen as carrier gas. Split ratio 20:1 with flow rate of $1.0 \mathrm{ml} / \mathrm{min}$, $0 \mathrm{ml} /$ minimum, inlet temperature $250^{\circ} \mathrm{C}$, and column type $\mathrm{HP}-5$ with $30 \mathrm{~m} \times .25 \mathrm{~mm} \times .25 \mu \mathrm{m}$ column dimensions. Oven temperature: initial temperature @ $50^{\circ} \mathrm{C}$ for $2 \mathrm{~min}$, detector temperature maintained 3200C; pressure 20psi and compressed air pressure 30 psi.

\subsection{Mineral content, mineral ratio and phytate deter- mination}

Wet digestion of samples $(5 \mathrm{ml})$ using a mixture of concentrated $\mathrm{HNO}_{3}$ and $60 \%(\mathrm{v} / \mathrm{v}) \mathrm{HClO}_{4}$ was carried out according to the method of AOAC (1990) where the organic matter in the sample was digested and afterwards diluted to a final volume of $25 \mathrm{ml}$ with deionized distilled water. The levels of $\mathrm{Na}, \mathrm{K}, \mathrm{Ca}, \mathrm{Fe}, \mathrm{Mg}, \mathrm{P}$, $\mathrm{Mn}, \mathrm{Cu}$, and $\mathrm{Zn}$ in the samples were thus evaluated using an atomic absorption spectrophotometer (Buck Scientific model 210 VGP) and flame photometer (Jenway model). The sulphate contents of the food samples were determined turbidimetrically according to AOAC (1984). The chloride level was determined titrimetrically using the method of AOAC, (1984).

\section{Results and discussion}

The proximate composition of various extracts of Azadirachta indica is shown in Fig. 1 below.

The moisture content of the aqueous extract was significantly $(p<0.05)$ higher than that for the methanol, and ethanol extract. The moisture contents of the three extracts were all higher than the reports for neem plant shown by Kashif and Ullah, (2013) and Madaki et al., (2016). The ash contents of all the extracts were comparable while the ethanol extracts produced the highest amount of fibre. The ash and fibre content of this plant under study were lower than those for Sida acuta (Enin et al., 2014), Vernonia amygdalina, and Gongronema latifolium (Atangwho et al., 2009). The implication with such low fibre content is that the leaves of Neem plant might not be suitable to relieve constipation. The ash content may imply poor mineral composition of this plant under study. The result of Fig. 1 showed methanol as the most suitable solvent in the extraction of fats and proteins. The fat and protein content of the methanol extract was in agreement with the reports of Atangwho et al., (2009) for Neem plant, and higher than those for Occimum tenniflorumi (Kashif and Ullah) and Withania somnifera leaves (Ishfaq and Farrukh, 2015). No significant difference $(p>0.05)$ was observed for the carbohydrate contents extracted with either water or ethanol. The carbohydrate content of the ethanol extracts was comparable to that of Emilia coccinea but lower than that of Anthecleista djalonensis, Spigella anthelmia and Ageratum conyzoides (Nduche et al., 2015). 


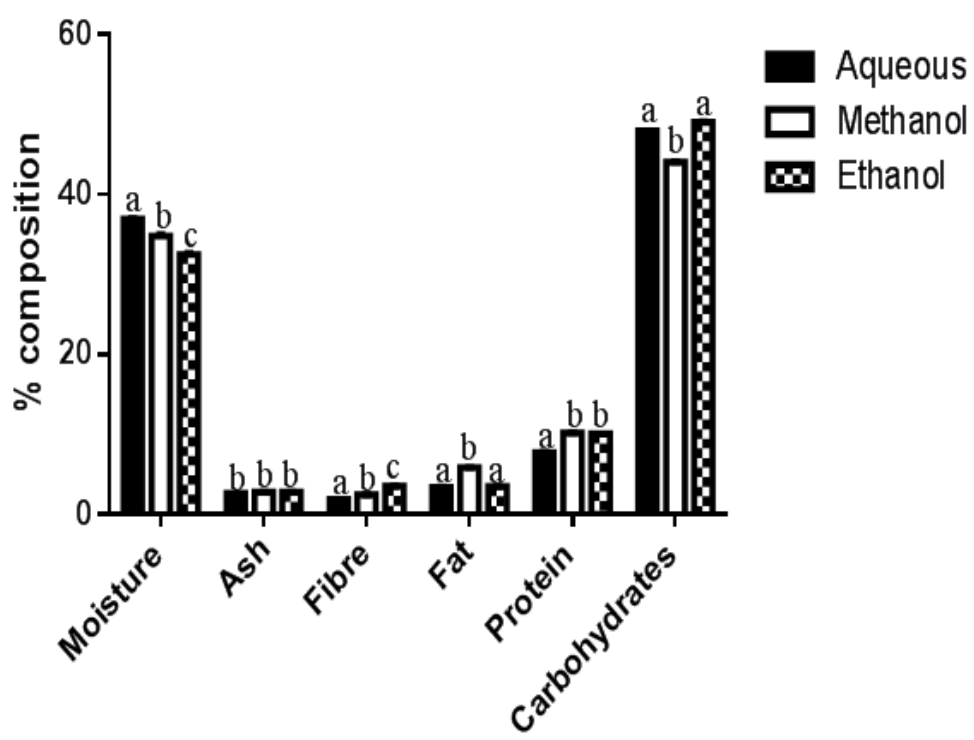

Fig. 1: Proximate Composition of Different Extracts of Plant Bars with Similar Superscript Letter (A, B, C) are Not Significantly Different (P > 0. 05)

Table 1: Phytochemical Screening of Various Extracts of Neem Plant

\begin{tabular}{|c|c|c|c|}
\hline Phytochemicals & Aqueous extract & Methanol extract & Ethanol extract \\
\hline Alkaloids & + & + & + \\
\hline Carbohydrates & + & + & + \\
\hline Reducing Sugars & + & + & + \\
\hline Flavonoids & + & + & + \\
\hline Tannins & + & + & + \\
\hline Phenols & + & + & + \\
\hline Triterpenoids & - & + & + \\
\hline Oxalate & + & + & + \\
\hline Glycosides & _ & - & - \\
\hline Steroids & & + & + \\
\hline
\end{tabular}

+ means present, - means absent.

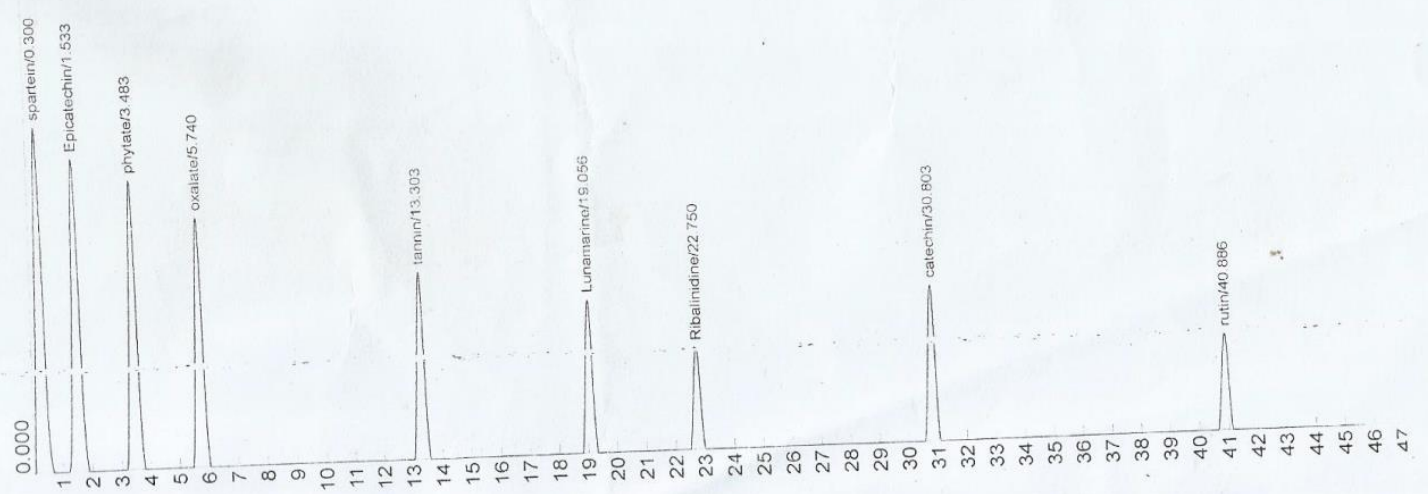

Fig. 2: Chromatogram for Phytochemical Analysis of Neem Plant Aqueous Extract. 


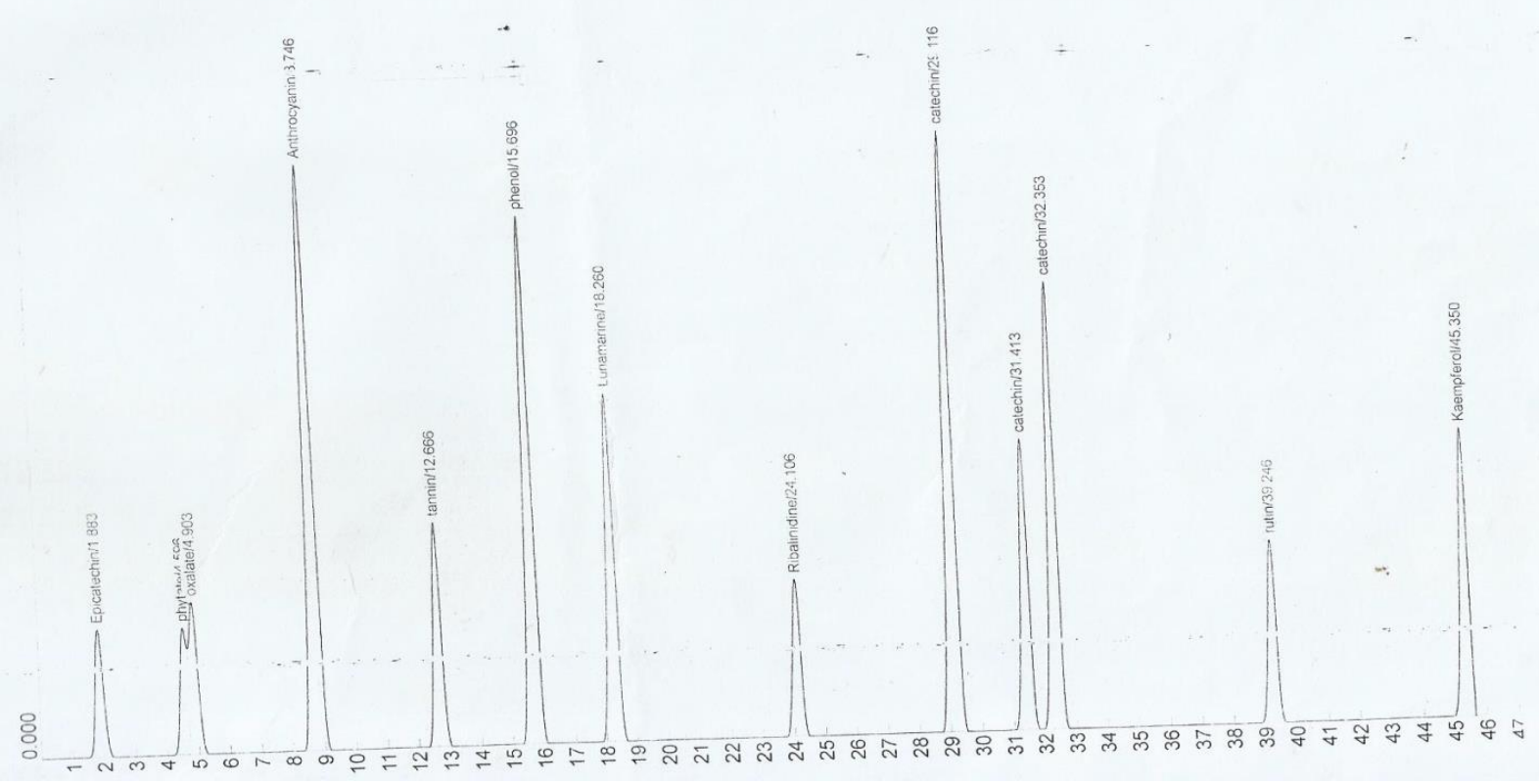

Fig. 3: Chromatogram for Phytochemical Analysis of Neem Plant Methanol Extract.

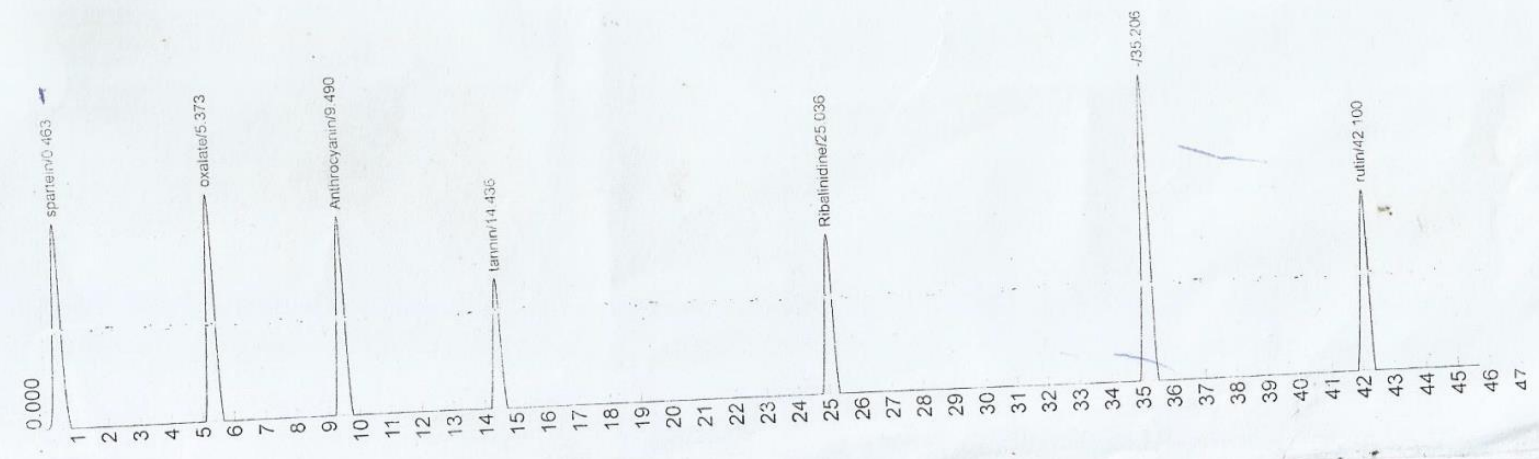

Fig. 4: Chromatogram for Phytochemical Analysis of Neem Plant Ethanol Extract.

Table 2: Phytochemical Analysis of Various Extracts of Neem Plant

\begin{tabular}{|c|c|c|c|}
\hline Phytochemical & Aqueous extract (\%) & Methanol extract (\%) & Ethanol extract (\%) \\
\hline Sparteine & 0.03 & ND & 0.05 \\
\hline Epicatechin & 13.42 & 11.60 & ND \\
\hline Oxalate & 1.03 & 0.18 & 1.23 \\
\hline Ribalinidine & 1.04 & 1.05 & 2.06 \\
\hline Catechin & 25.85 & 27.34 & ND \\
\hline Phenol & ND & 4.3 & ND \\
\hline Rutin & 34.40 & 26.40 & 77.54 \\
\hline Lunamarin & 5.81 & 3.78 & ND \\
\hline Tannin & 19.18 & 16.3 & 17.76 \\
\hline Phytate & 0.27 & 0.02 & 0.20 \\
\hline
\end{tabular}

ND means not detected

The result for the qualitative phytochemical composition of Azadirachta indica is shown in Table 1 . The results confirm the presence of alkaloids, carbohydrates, reducing sugars, flavonoids, tannins, phenols, and saponins. A similar result was reported by Njoku and Obi, (2009) for C. papaya and Adenia cissampeloides. Alkaloids are known to confer several essential physiological effects on humans and animals. The very bitter taste of this plant under study may be attributed to its tannin content. The presence of flavonoids and phenos indicate a possible antioxidant property of $A$. indica. Only ethanol and methanol extracts showed the presence of triterpenoids and steroids. Siddiqui et al., (2000) have isolated nimocinol, a triterpenoid from neem plant, with possible insecticidal activity against Aedes aegypti. The presence of steroids in neem plant has also been confirmed in similar studies (Ejoba, 2012). Ejoba, (2012) reported the absence of saponins from aqueous extract of neem plant, which is not in line with the findings of this present study. The presence of saponins indicates possible usage of these plant extracts as a cleaning agent. Oxalate 
was not confirmed in only the ethanol extracts of this plant while no glycoside activity was recorded in any of the extracts. Fig. 2-5 shows the chromatograms for the phytochemical analysis of various extracts of $A$. indica. Table 2 shows the phytochemical analysis of aqueous, methanol, and ethanol extracts of $A$. indica. Among the three extracts used, methanol proved the least effective in extraction of the alkaloid; sparteine, lunamarine, and ribalinidine. The forkloric claims of this plant usage in medicine for the stimulation of the cardiac and uterine muscles in childbirth might be related to these alkaloid activities. The phenol epicatechin and catechin were highest in the aqueous and methanol extract respectively, while total phenol was only found in the methanol extract. The phenols' catechin and epicatechin have been found to improve various heart conditions most especially normalizing blood pressure. This might be the reason behind the prescription of neem plant by herbalists, for antihypertension therapy. The oxalate levels of both ethanol and aqueous extracts were higher than the methanol extracts. Osuntokun and Oluwafoise, (2015) reported higher oxalate contents for Pseudocedrela kotschyi when compared to those presented for the various extracts in this study while the report of Nwachoko and Jack, (2015) for Tetracarpidium conophorum was lower than that for A. indica in this study. The low oxalate composition indicates minimal or no digestive difficulties that could result from the consumption of the extracts of $A$. indica. The results for the flavonoids; anthocyanin, rutin, and kaempferol, showed that ethanol proved most effective in the provision of the flavonoids with the exception of kaempferol undetected in both aqueous and ethanol extract. The high rutin content of this plant may be in support of the reports of Shitlania et al. (2016) that reported the ameliorative antimalarial effects of the combination of rutin. Also, the very high rutin content may be connected to the antidiabetic activity of neem plant with respect to the findings of Niture et al., (2014) on thea Anti-hyperglycemic activity of rutin in streptozotocin-induced diabetic rats. In addition, the rutin and the kaempferol content of $A$. indica provide the scientific backing behind it antimicrobial properties (Reddy et al. 2013). The aqueous extract provided the highest antinutrients (phytates and tannins). A. indica leave is a very bitter tasting plant. This astringency could be as a result of tannin content. None of the medicinal plant leaves; Bauhinia cheilantha, Capparis jacobinae Moric, Nicotiana glauca, Lantana camara, and Croton rhamnifolius examined by Clarissa et al., (2012) contained any comparable tannin content. The phytate compositions of the aqueous and ethanol extract of $A$. indica in this study were comparable to those for Vernonia amygdalina, Gnetum Africanum, Piper guinensis, and Pterocarpus santolinoides (Odoemelam et al., 2015). The formation of stable complexes of divalent metals by phytates from phytate-rich foods, might not be an obtainable case with the various extracts of $A$. indica in this study, having shown low and comparable phytate compositions similar to popularly consumed vegetables.

Table 3: Vitamin Contents of Various Extracts of Neem Plant

\begin{tabular}{llll}
\hline Vitamins $(\mathrm{mg} / 100 \mathrm{~g})$ & Aqueous & Methanol & Ethanol \\
\hline Vitamin A & $0.34 \pm 0.01^{\mathrm{a}}$ & $0.12 \pm 0.01^{\mathrm{b}}$ & $0.29 \pm 0.04^{\mathrm{a}}$ \\
Vitamin D & $0.75 \pm 0.14^{\mathrm{a}}$ & $0.77 \pm 0.04^{\mathrm{a}}$ & $0.69 \pm 0.11^{\mathrm{a}}$ \\
Vitamin E & $2.95 \pm 0.08^{\mathrm{a}}$ & $1.09 \pm 0.06^{\mathrm{b}}$ & $2.60 \pm 0.07^{\mathrm{c}}$ \\
Vitamin K & $\mathrm{ND}$ & $0.08 \pm 0.01$ & $\mathrm{ND}$ \\
Vitamin C $_{\text {Vitamin } \mathrm{B}_{1}}^{36.86 \pm 0.30^{\mathrm{a}}}$ & $22.80 \pm 0.43^{\mathrm{b}}$ & $35.71 \pm 0.51^{\mathrm{a}}$ \\
Vitamin B $_{2}$ & $1.55 \pm 0.20^{\mathrm{a}}$ & $0.89 \pm 0.14^{\mathrm{b}}$ & $0.83 \pm 0.18^{\mathrm{b}}$ \\
Vitamin $_{3}$ & $0.15 \pm 0.04^{\mathrm{a}}$ & $0.10 \pm 0.02^{\mathrm{a}}$ & $0.13 \pm 0.08^{\mathrm{a}}$ \\
\hline
\end{tabular}

Values are means \pm S.D of triplicate determinations. Values bearing dissimilar superscript letter $(a, b, c)$ are significantly different $(\mathrm{p}<0.05)$.

The vitamin compositions of various extracts of $A$. indica are shown in Table 3 . The vitamin a content of the methanol extracts $(0.12 \mathrm{mg} / 100 \mathrm{~g})$ was the least in occurrence, while no significant change was recorded between the vitamin A content obtained from both the aqueous $(0.34 \pm 0.01)$ and ethanol extract $(0.29 \pm$ 0.04). The level found in this study for vitamin A content was higher than that of Acalypha wilkesiana (Ikewuchi and Ikewuchi,
2009). No significant difference was recorded among the vitamin D contents of the three extracts, while the aqueous extract provided the highest content of vitamin $\mathrm{E}$ among the three extracts. Vitamin $\mathrm{K}$ was undetected in both aqueous and methanol extract of $A$. indica in this study. The levels of these fat-soluble vitamins in all the extracts shown in Table 3, were higher than those from the reports of Ikewuchi and Ikewuchi, (2009) for Acalypha wilkesiana, Chromolaena odorata, and Tridax procumbens. With these levels found in this study, in comparison to the RDA for the vitamins, the neem plant is an inadequate source for vitamin $\mathrm{A}$ and $\mathrm{E}$, while the vitamin D and $\mathrm{K}$ levels at $100 \mathrm{mg}$ was found sufficient. Vitamin A plays an important role in the maintenance of good vision, while vitamin D enhances the calcium homeostasis as well as promotes the uptake of phosphorus and calcium (BertoneJohnson et al., 2005). Vitamin E is an important antioxidant that helps to relieve the body of oxidative stress while vitamin $\mathrm{K}$ is need for the activation of the several vitamin K-dependent clotting factors through its calcium binding potentials. Both the aqueous and ethanol extracts provided the highest vitamin $\mathrm{C}$ content (36.86 $\mathrm{mg} / 100 \mathrm{~g}$ and $35.71 \mathrm{mg} / 100 \mathrm{~g}$ respectively). The vitamin $\mathrm{C}$ contents of the various extracts of neem plant in this study, was higher than those for the vegetables; Portulaca oleracea Allium sativum, and Hibiscus esculentus (Bangash et al., 2011) while Spinacea oleracea and Momordica charantia (Bangash et al., 2011) provided better sources of vitamin $\mathrm{C}$, than the neem plant in this present study. Vitamin $\mathrm{C}$ is a well-known antioxidant, and as plays a role during the synthesis of derivatives of folic acid, essential for DNA synthesis (Chatterjea and Shinde, 1998). The thiamine (vitamin $\left.B_{1}\right)$ content of the aqueous extract of neem plant $(1.55 \mathrm{mg} / 100 \mathrm{~g})$ as shown in Table 3 was significantly $(\mathrm{p}<0.05)$ higher than those for methanol $(0.89 \mathrm{mg} / 100 \mathrm{~g})$ and ethanol extract $(0.83 \mathrm{mg} / 100 \mathrm{~g})$. These values were higher than the reports of Okwu (2005) for Aframomum melegueta and Garcinia kola. Thiamine is involved in muscle function and nervous system, movement of electrolytes, and the digestive system. Further, no significant difference was recorded for the vitamin $\mathrm{B}_{2}$ composition among the three extracts studied, while the usage of methanol for extraction proved most yielding for niacin (vitamin $\mathrm{B}_{3}$ ) extraction. The riboflavin levels recorded in this study were lower than those for Ranunculus arvensis, Equisetum ravens, Carathamus lanatus and Fagonia critica (Hussain et al., 2011). The niacin content of the methanol extracts of neem plant in this study was comparable to that of garlic (Allium sativum), mustard (Brassica campestris) and bath sponge (Luffa acutangula), but lower than that of spinach (Spinacea oleracea) and egg plant (Solanum melongena) as reported by (Bangash et al., 2011). Riboflavin functions as a coenzyme and is required for numerous physiological functions such as cellular respiration Beta oxidation, vision, etc., and while niacin is useful for the treatment of pellagra and hypercholesterolemia.

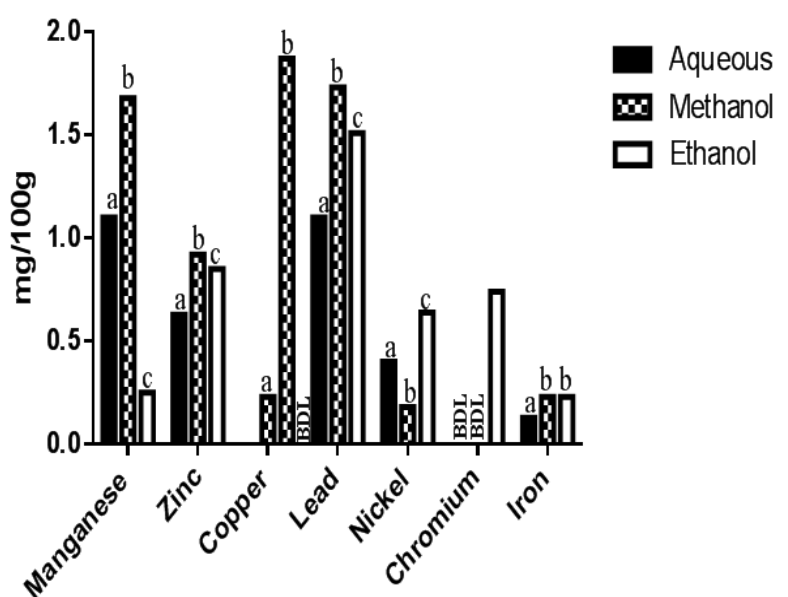

Fig. 5: Micro Mimeral Content of Various of Neem Plant BDL Means below Detection Levels. Bars with Similar Superscript Letter (A, B, C) are Not Significantly Different $(\mathrm{P}>0.05)$. 
The micro mineral composition of various extracts of neem plant was shown in Fig. 5. The methanol extracts produced the significantly highest amount of manganese, zinc, copper and lead. The manganese and zinc contents of all the extracts of neem plant evaluated in this study were lower than those for Pseudocedrela kotschyi, Anogeissus leiocarpus, Terminalia glaucescens and Zanthoxylun Lessmamul (Osuntokun and Oluwafoise, 2015) while the copper and lead contents presented in this study for the extracts were higher than those for Carica papaya, Nicotiana tabacum, Morinda lucida and Piper guineense (Osuntoken, 2015). Zinc and manganese are both essential constituents of many enzymes and are required for their various activities while copper is required during the onset of haemopoiesis. The result of this study for lead suggests possible toxic effects that could arise from excessive consumption of neem plant. Further, ethanol provided the highest amount of nickel and chromium, though, chromium was undetected in both aqueous and methanol extract of the neem plant (Fig. 5). The result further indicated that methanol and ethanol provided a comparable amount of iron. Chromium was found below detection levels in the aqueous and methanol extracts whereas the chromium levels of the ethanol extract of neem plant in this study was not in agreement with the reports of Atangwho et al., (2009), though higher than those for $V$. amygdalina and $G$. latifolium (Atangwho et al., 2009), while the nickel content was higher than that reported by Offor, (2014). The lead contents of the methanol and ethanol content presented in this study were comparable.

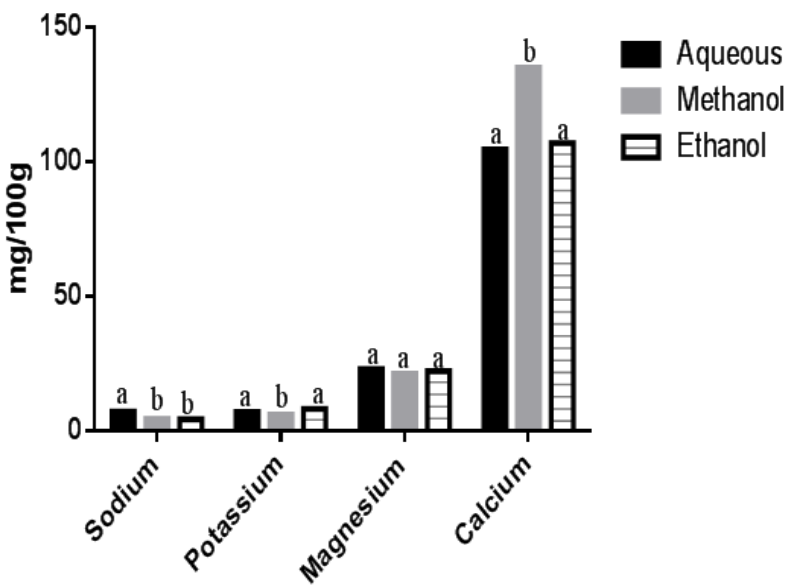

Fig. 6: Macro Mineral Content of Various Extracts of Neem Plant. Bars with Similar Superscript Letter (A, B, C) are Not Significantly Different (P $>0.05)$.

The macro mineral content of various extracts of neem plant was presented in Fig. 6. No significant difference $(p>0.05)$ was recorded between the sodium content of the methanol and ethanol content of neem plant evaluated in this study. Ethanol produced the highest sodium content, and was higher than those for G. kola and A. melegueta (Okwu, 2005) but lower than that of M. utilis (Ujowundu et al., 2010). For the potassium content, both the ethanol and aqueous extract produced comparable amounts. From the reports of Enin et al., (2014) S. acuta produced higher potassium contents than that of neem plant in this study. $P$. guineense, $P$. umbellatum, and $S$. striatinux (Armand et al., 2013) similarly produced higher potassium contents than neem plant in this study. Further, the result indicated that all the extracts comparable amounts of magnesium. The medicinal plants; Anogeissus leiocarpus, Terminalia glaucescens, and Zanthoxylun Lessmamul according to Osuntokun and Oluwafoise, (2015) possessed similar amounts of magnesium compared to the neem plant in this study. In this study, the usage of methanol for extraction was most effective for the extraction of calcium (Fig. 6). No significant change was found for the calcium content of the aqueous and ethanol extract. The findings of this study for the calcium content were not in agreement with the reports of Sahito et al., (2003).

\section{Conclusion}

The current study of the analysis of different extracts of Azadirachta indica will enhance the applicability of this medicinal plant in various pharmaceutical and therapeutic processes. The findings of this study were indicative of general suitability of ethanol for extraction of proximate contents, aqueous extracts for vitamins, while methanol extracts provided the highest amounts of phytochemicals and minerals.

\section{Conflict of interest}

The authors declare no existing conflict of interest regarding this article.

\section{References}

[1] Abdel Moneim, A.E. (2014) "Azadirachta indica attenuates cisplatininduced neurotoxicity in rats," Indian Journal of Pharmacology, 46(3), pp. 316-321. https://doi.org/10.4103/0253 7613.132182.

[2] Abdel Moneim, A.E. Othman, M.S. and Aref, A.M. (2014) "Azadirachta indica attenuates cisplatin-induced nephrotoxicity and oxidative stress," BioMed Research International, vol. 2014, Article ID647131, 11 pages.

[3] AOAC (2006). Official Methods of Analysis of AOAC (Horwitz,W editor) 18th edition. Association of Official Analytical Chemists Washington, DC, USA

[4] AOAC. (1984). Standard Official Methods of Analysis of the Association of Analytical Chemists. 14 Edn., Association of Analytic Chemists, Washington DC.

[5] AOAC. (1990).Official methods of analysis (15thedn.,).Washington DC, USA. Association of official analytical chemists inch 400-2200 Wilson Boalevard, Arlinton Virginia USA, 2: 910-92.

[6] Armand, A.B., Nicolas, Y.N., Harquin, S.F., Joel, S., Didier, M. Carl, M. and Mbofung, F. (2012) Proximate Composition, Mineral and Vitamin Content of Some Wild Plants Used as Spices in Cameroon, Food and Nutrition Sciences, 3, 423-432 https://doi.org/10.4236/fns.2012.34061.

[7] Atangwho, I. J., Ebong, P. E., Eyong, E. U. Williams, I. O. Eteng, M. U. and Egbung, G. E. (2009) Comparative chemical composition of leaves of some antidiabetic medicinal plants: Azadirachta indica, Vernonia amygdalina and Gongronema latifolium. African Journal of Biotechnology 8 (18), pp. 4685-4689.

[8] Baligar, N. S. Aladakatti, R. H., Ahmed, M. and Hiremath, M. B. "Evaluation of acute toxicity of neem active constituent, nimbolide and its hepatoprotective activity against acute dose of carbon tetrachloride treated albino rats," International Journal of Pharmaceutical Sciences and Research, ( 5) 8, pp. 3455-3466, 2014.

[9] Bangash, J.A. Muhammad, A., Faizullah, K., Faridullah, K., AminUr-Rahman and Iqbal. H. (2011) Proximate Composition, Minerals and Vitamins Content of Selected Vegetables Grown in Peshawar, J.Chem.Soc.Pak., 33 (1), 118-121

[10] Bertone-Johnson, E.R., Hankinson, S.E., Bendich, A., Johnson, S.R., Willett, W.C. and Manson, J.E. (2005) Calcium and vitamin $\mathrm{D}$ intake and risk of incident premenstrual syndrome. Arch Intern Med. https://doi.org/10.1001/archinte.165.11.1246.

165(11):1246-52.

[11] Bhanwra, S. (2000) "Effect of Azadirachta indica (neem) leaf aqueous extract on paracetamol induced liver damage in rats," Indian Journal of Physiology and Pharmacology, vol. 44, no. 1, pp. $64-68$.

[12] Bharti,R., Ahuja,G., SujanGanapathy,P.S. and Dakkappa, S.S. (2012). A review of medicinal palnts having antioxidant potential. Journal of Pharmacy Research. 5(8):4278 - 4287.

[13] Callahan, C. (2010). 'Uses of Neem Datun for teeth'. Living strong .com. Demand Media.

[14] Chatterjea, M. N. and Shinde, R. (1998) Text Book of Medical Biochemistry. Jaypee Brothers Medical Publishers, 173.

[15] Clarissa, F., Daniela, L., Tadeu, J., Elba, L., Joabe, G., Thiago, A. and Ulysses, P. (2012) Levels of Tannins and Flavonoids in Medicinal Plants: Evaluating Bioprospecting Strategies, EvidenceBased Complementary and Alternative Medicine Volume 2012 , Article ID 434782, 7 pages https://doi.org/10.1155/2012/434782. 
[16] Dingman, S.L. (2002). Water in soils: infiltration and redistribution. Physical hydrology, second edition, upper saddle river, New Jersey: Prentice-Hall, Inc. p. 646.

[17] Durrani, F.R. Chand, N. Jan, M. Sultan, A. Durrani, Z. and Akhtar, S. "Immunomodulatory and growth promoting effects of neem leaves infusion in broiler chicks," Sarhad Journal of Agriculture, 24, pp. 655-659, 2008

[18] Ejoba, R. (2012) Phytochemical constituents of some leaves extract of Aloe vera and Azadirachta indica plant species Global Advanced Research Journal of Environmental Science and Toxicology, 1(2) pp. 014-017.

[19] Enin, G. N. Antia, B. S. and Enin, F. G. (2014) Chemical assessement of the proximate, minerals, and anti-nutrients composition of Sida acuta leaves, Elixir Org. Chem. 7124654 24660

[20] Ghimeray, A. K. Jin, C. W. Ghimire, B. K. and Cho, D. H. (2009) "Antioxidant activity and quantitative estimation of azadirachtin and nimbin in Azadirachta indica A. Juss grown in foothills of Nepal," African Journal of Biotechnology, (8)13, pp. 3084-3091.

[21] Girish, K.and Neem, S. B. S. “A green treasure,” Electronic Journal of Biology, 4, pp. 102-111, 2008.

[22] Harborne, J. B. (1973). Photochemical methods. A guide to modern Technique of plant Analysis. 2nd edn. Chapman and Hall, New York.

[23] Hoffman, P.C., Combs, D.K. and Casler, M.D. (1998). Performance of lactating dairy cows fed alfalfa silage or perennial ryegrass silage. J. Dairy Sci. 81: 162-168. https://doi.org/10.3168/jds.S00220302(98)75563-8.

[24] Hussain, I., Ullah, R., Ullah, R., Khurram, M. Ullah, N. Baseer, A. Khan, F.A. and Khattak, M.R. (2011) Phytochemical analysis of selected medicinal plants, African Journal of Biotechnology, (38), pp. 7487-7492

[25] Ikewuchi, C.C. and Ikewuchi, J.C. (2009) Comparative Study of the Vitamin Composition of Some Common Nigerian Medicinal Plants. The Pacific Journal of Science and Technology 10(1) 367-371

[26] Ishfaq, H. and Farrukh, H.( 2015) Proximate and elemental analysis of five selected medicinal plants of family Solanaceae, Pak. J. Pharm. Sci., 28(4), pp.1203-1215

[27] Kashif M. and Ullah, S. (2013). Chemical Composition and Minerals Analysis of Hippophae rhamnoides, Azadirachta indica, Punica granatu and Ocimum sanctum Leaves World Journal of Dairy \& Food Sciences 8 (1): 67-73, DOI: 10.5829/idosi.wjdfs.2013.8.1.1119

[28] Kaur, G., Sarwar Alam, M. and Athar, M. "Nimbidin suppresses functions of macrophages and neutrophils: relevance to its antiinflammatory mechanisms," Phytotherapy Research, 18(5), pp. 419-424, 2004. https://doi.org/10.1002/ptr.1474.

[29] Krishan, N., Swetanus P., Prachian, J., Prakhar, G., Raski Chaudhary, S., Viaidyanathan, P.G., Bharath, K. and Binary Panda. (2011).' 'De novo sequencing and assembly of Azadirachta indica fruit transcriptome', Current Science 101(12): 1553- 1561.

[30] Kumar, D.S., Sharathnath, K.V., Yogeswaran, P., Harani, A., Sudhakar, K., Sudha, P. and Banji, D. (2010). A medicinal Potency of Momordica charantia. International Sciences Review and Research 1(2), 95-100

[31] Latif, A., Ahmad, H., Begum, S., Adnan, M., Hussian, S. and Waseem, M. (2003). Medicinal and other economic plants as substitute to forest logging in Miandam and Sulatanr valleys, Swat. Proceedings of international workshop on conservation and sustainable use of medicinal and aromatic plants in Pakistan WWF-Pak. 101-105.

[32] Matthews, H.B., Lucier, G.W. and Fisher, K.D. (1999) Medicinal herbs in the United States: Research needs. Environ. Health Perspect., 107, 773-778. https://doi.org/10.1289/ehp.99107773.

[33] Mosaddek, A. S. M. and Rashid, M. M. U. "A comparative study of the anti-inflammatory effect of aqueous extract of neem leaf and dexamethasone," Bangladesh Journal of Pharmacology, 3(1), pp. 44-47, 2008. https://doi.org/10.3329/bjp.v3i1.836.

[34] Natarajan, V., Venugopal, P. V. and Menon, T. (2003) "Effect of Azadirachta indica (Neem) on the growth pattern of dermatophytes," Indian Journal of Medical Microbiology, 21(2), pp. 98-101.

[35] Nduche, M. U., Edeoga, H. O., Omosun, G. And Nwankwo, D. (2015) Evaluation of the Chemical Composition of Five Nigerian Medicinal Plants IOSR Journal of Pharmacy and Biological Sciences (IOSR-JPBS), 10(2), PP 27-31

[36] Niture, N.T., Ansari, A.A. and Naik, S.R. (2014) Antihyperglycemic activity of rutin in streptozotocin-induced diabetic rats: an effect mediated through cytokines, antioxidants and lipid biomarkers. Indian J Exp Biol. 52(7):720-7.

[37] Njoku, O. V. and Obi, C. (2009) Phytochemical constituents of some selected medicinal plants African Journal of Pure and Applied Chemistry, 3 (11), pp. 228-233.

[38] Nwachoko, N. and Jack, I. R. (2015) Phytochemical screening and antidiarrhoea activities of Tetracarpidium conophorum induce in albino rats Sky Journal of Biochemistry Research Vol. 4(3), pp. 016 -020 .

[39] Odoemelam, S.A, Ifenkwe, O.I.O., Okoro, E.K. and Okechukwu, C.R. Phytochemical and heavy metals determination in leafy vegetables consumed in Eastern Nigeria, World Journal of Pharmaceutical Research, 4(11), 177-192.

[40] Offor, C.E. (2014) Comparative Chemical Analyses of Vernonia amygdalina and Azadirachta indica Leaves IOSR Journal of Pharmacy and Biological Sciences (IOSR-JPBS) 9(5) PP 73-77

[41] Okwu, D.E. (2005). Phytochemicals, Vitamins and Mineral contents of two Nigeria Medicinal plants. Int. J.Mol. Med. Adv. Sci. 1(4): 375-381.

[42] Osuntokun, O.T. (2015) Comparative Study of Antibacterial and Phytochemical Properties of Nigerian Medicinal plants on Salmonella bongori and Salmonella enteritidis Isolated from Poultry Feaces in Owo local Government. Ondo State, Nigeria, Journal Archives of Current Research International, 2(1):1-11

[43] Osuntokun, O.T. and Oluwafoise B.O. (2015) Phytochemical screening of ten Nigerian medicinal plants. International Journal of Multidisciplinary Research and Development 2(4), 390-396

[44] Prajapati, N.D. and Prajapati, T. (2002). Sustainable cultivation of medicinal plants; Multi tier agriculture system-A new concept. URL www.techno-preneur.net/timeis/technology

[45] Reddy R.R.Y, Krishna, K.C., Lokanatha, O., Mamatha, S. and Damodar, R.C. (2013) Antimicrobial activity of Azadirachta Indica (neem) leaf, bark and seed extracts Int. J. Res. Phytochem. Pharmacol. 3(1), 1-4

[46] Sahito S.R, Memon, M.A. Kazi, T.G and Kazi, G.H. (2003). Evaluation of Mineral content in medicinal plant Azadirachta indica (neem).J. chem. Soc.Pak 25(2): 139-143.

[47] Shinwari, Z.K., Rehman, M., Watanabe, T. and Yoshikawa, T. (2006). A Pictorial guide to medicinal plants of Pakistan. Kohat University of Science and Technology Pakistan.

[48] Shitlani, D. Choudhary, R. Pandey, D.P. and Bodakhe, S.H. (2016) Ameliorative antimalarial effects of the combination of rutin and swertiamarin on malarial parasites, Asian Pacific Journal of Tropical Disease 6(6), Pages 453-459 https://doi.org/10.1016/S2222-1808(16)61067-8.

[49] Siddiqui, B.S., Afshan, F., Faizi, S., Naqvi, S.N. Tariq, R.M. (2000) Two Insecticidal Tetranortriterpenoids From Azadirachta Indica Phytochemistry 53 (3), 371-376.

[50] Sithisarn, P. Supabphol, R. and Gritsanapan, W. (2005) "Antioxidant activity of Siamese neem tree (VP1209)," Journal of Ethnopharmacology, 99(1), pp. 109-112. https://doi.org/10.1016/j.jep.2005.02.008.

[51] Sofowora, A. (1980). Guidelines for research promotion and development in traditional medicine Nig. J. Pharmacy. 11:117-118.

[52] Ujowundu, C.O., Kalu, F.N., Emejulu, A.A., Okafor, O.E., Nkwonta, C.G. and Nwosunjoku, E.C. (2010) Evaluation of the chemical composition of Mucuna utilis leaves used in herbal medicine in Southeastern Nigeria African Journal of Pharmacy and Pharmacology, 4(11), pp. 811-816. 